\title{
METAMORFOSE: SILÊNCIO E VIDA NA TRANSLATIO DE MUNDOS
}

\section{METAMORPHOSIS: SILENCE AND LIFE IN THE TRANSLATIO OF WORLDS}

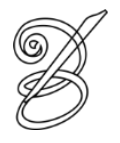

Hugo SIMÕES ${ }^{i *}$

Universidade Federal do Paraná

Curitiba, Paraná, Brasil

Resumo: O silêncio, fundamental à criação artística que vai do modernismo ao período contemporâneo, é investigado, neste artigo, fora de seu paradigma citadino, a fim de se repensar o que é e o que pode ser tradução. Para tanto, mobiliza-se ideias de Paul Celan, Davi Kopenawa, Walter Benjamin, Alexandre Nodari e Emanuele Coccia, dentreoutros, tendo como objetivo cruzar ideias como memória, antropologia especulativa, biofonia, poética e xamanismo no delineamento do que seja uma translatio de mundos: a metamorfose. O silêncio ligado à ideia da biofonia se manifesta como vida, o que abre novas margens à "tarefa do tradutor", dentre as quais o contato com o foris, como a floresta. Nessa chave, um poema de Paul Celan é traduzido como decorrência de uma "arqueologia especulativa", ou seja, de uma nova perspectiva sobre a atenção dada ao poema e ao ambiente que o cercou e o cerca.

Palavras-chave: Silêncio. Metamorfose. Arqueologia Especulativa. Paul Celan. Vida.

Abstract: Silence, fundamental to artistic movements from modernism to the contemporary period, is investigated outside of its urban paradigm in this article, in order to rethink what is and what can be translation. In order to do so, the ideas of Paul Celan, David Kopenawa, Walter Benjamin, Alexandre Nodari and Emanuele Coccia, among others, are mobilized. The objective is to cross ideas such as memory, speculative anthropology, biophony, poetry and shamanism in the design of a translatio of worlds: the metamorphosis. Silence bounded to the idea of biophony manifests itself as life, which opens new margins to the "task of the translator", among which the contact with the foris, such as the forest. In this way, a poem of Paul Celan is translated as a result of a "speculative archeology", that is, a new perspective on the attention given to the poem and the environment that surrounded it and surrounds it.

Keywords: Silence. Metamorphosis. Speculative Archeology. Paul Celan. Life.

RECEBIDO EM: 5 de setembro de 2019

ACEITO EM: 17 de fevereiro de 2020

PUBLICADO EM: março 2020 
Se viver é respirar é porque nossa relação com o mundo não é a do estar-lançado ou do estar-dentro-do-mundo, nem mesmo a do domínio de um sujeito sobre um objeto que está diante dele: estar-no-mundo significa fazer a experiência de uma imersão transcendental. A imersão de que o sopro é a dinâmica originária - se define como uma inerência ou uma imbricação recíproca. Estamos em alguma coisa com a mesma intensidade e a mesma força com que ela está em nós. É a reciprocidade da inerência que faz do sopro uma condição sem saída: impossível se liberar do meio no qual se está imerso, impossível purificar esse mesmo meio de nossa presença.

Emanuele Coccia

\section{Introdução}

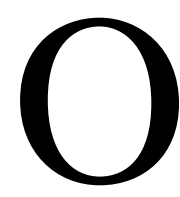

silêncio permeia o fazer tradutório, é uma possibilidade de fazer ouvir outra vida. Proponho neste artigo uma tentativa de imaginar o traduzir como escuta de foris raiz de floresta -, o exterior que persiste como linha de fuga do Estado (NODARI, 2013, p. 256).A minha hipótese é de que apura língua (BENJAMIN, 2016, p. 101-119) é o virtual sempre acessível do tempo mítico em que tudo falava, podendo, portanto, ser atualizada no silêncio da floresta, como escutado por Davi Yanomami (2015). Escrevo aqui sobre

14 tradução, equívoco de metamorfose, em sua possível relação com silêncios outros, os quais ressoam a biofonia de foris, a polifonia da mata (ALBERT, 2018) que vive em sua infinita multiplicidade e multiplicação. Nessa relação, a analogia xamânica - do tradutor enquanto especialista em transformação corporal - é fundamental ao que proponho como método de tradução: a metamorfose, uma técnica de vida. Para chegar a isso, mobilizo muito do que aprendi com Paul Celan, ao traduzir seus textos e poemas, e apresento uma tradução do poema “Das leise Gemerk" a partir da ideia de arqueologia especulativa. Antes de tudo, porém, faço uma pequena digressão (em que se assume o risco de generalizações) sobre o silêncio na poesia e na arte, tanto moderna quanto contemporânea, a fim de localizar o silêncio citadino como silêncio unívoco (ligado à ideia de ausência).

\section{O silêncio da cidade}

“A tradução é uma forma” que obedece à lei do original, pensava Walter Benjamin (2016: 102) há cerca de um século. Benjamin escreveu seu famoso "A Tarefa do Tradutor” movido por suas traduções de Charles Baudelaire - a modernidade e o mundo que devinha cidade eram, portanto, ambiência de sua teologia tradutória. Há pouco mais de um século, enquanto a urbe tomava o mundo, a língua era reimaginada e o silêncio se tornava o ponto nodal do verso e da arte; cavava-se, a modo mallarmaico, um imenso buraco com "o risco de transformar a matéria 
cavada num lugar abismal, num caos" (KEMPINSKA, 2008, p. 155). A arte moderna em seus limites últimos (os modernismos) pode ser vista como fruto (reprodução, pois) desse buraco intangível na língua, ou melhor, linguagem cavada, da exposição dos silêncios que ora foram nomeados caos, ora responderam por reordenação.Assim, no mundo moderno, a tradução poderia continuar a ser uma forma de reordenar, de artifício de fidelidade como artificialidade, ou poderia, como sugere Haroldo de Campos ao ler Benjamin, assumir sua tarefa satânica, de mensageiro (anjo) em permanente hybris (2008, p. 180), transgressão para dar nova origem. Em que pesem as divergências de métodos, a tradução moderna se localiza na urbe (seja em seu centro ou em seus limites), reverberando uma mesma lei do original: o silêncio enquanto algo unívoco.Como escreve David Lapoujade: "Provavelmente, essa é uma tendência que atravessa todas as artes, a tentativa de povoar novas entidades das zonas reputadas como estéreis ou inabitáveis para a sensibilidade" (2017, p. 110), algo que o filósofo identifica em diferentes produções artísticas, de Cage a Malevitch, as quais chegariam a um "limite intransponível", algo como a unicidade do silêncio.

No estágio tardio da modernidade, após a passagem do século XIX, surgem diversos movimentos artísticos conhecidos como modernismos, os quais tiveram início com diferentes perspectivas de vanguarda. Não me proponho aqui a me aprofundar sobre esses movimentos, mas gostaria de retomar um artista já citado, Stephane Mallarmé, cuja obra deu atençãoao silêncio na poesia e na arte. Em um famoso prefácio a Un coup de dés, obra mais radical do poeta lançada apenas duas décadas antes do ensaio tradutológico de W. Benjamin, lemos, em tradução de Haroldo de Campos:

Os 'brancos' com efeito assumem importância, agridem de início; a versificação os exigiu, como silêncio em derredor, ordinariamente, até o ponto em que um fragmento, lírico ou de poucos pés, ocupe, no centro, o terço mais ou menos da página: não transgrido essa medida, tão-somente a disperso. (MALLARMÉ, 2010, p. 151)

Lemos acima uma mudança de perspectiva modernista, dos "brancos" pensados como silêncio. Esse silêncio, todavia, era uma unívoca evidência, muda e nascida da cidade: um pano de fundo de dava novo foco à letra. Conjuntamente a essa nova atenção, a ideia mallarmaica de "crise de verso(s)" pode ser considerada como fulcralà arte que abriria um século de muitas crises. A crise seria o topos da arte moderna para Marcos Siscar, o qual lê o Crise de Vers (2010, p. 103-117) numa chave não melancólica: a crise seria a própria propulsão da arte moderna. A crise de verso não seria apenas a crise do verso tradicional (ainda que nela esteja englobada) e 
a libertação da poesia (com o verso livre), mas também uma nova visada sobre a arte e suas arestas ainda pouco exploradas.

A crise não designa um fato histórico que atinge a poesia, ou que teria conseqüências sobre a poesia, como normalmente se pensa, mas é um modo de nomear um estado de poesia, um determinado tratamento dispensado ao poema que oscila entre o repouso da tradição e o interregno interessantíssimo do "quase". (SISCAR, 2010, p. 215)

A crise passa também a se tornar uma tradição, ou melhor, a ressignificar a tradição. Em “Tradução, tradição, transculturação: o ponto de vista do ex-cêntrico", publicado originalmente em 1997, por meio de um retorno ao primeiro modernismo brasileiro e a suas propostas de devoração, Campos pensa a tradução como uma "tradição de invenção" que tem uma "forma ativa de pedagogia" (2013, p. 204). A crise que permeia os modernismos ao longo do século XX, possibilitando tal tradição inventiva, acompanha certo êxodo e certo prenúncio de futuro: um futuro que se distancia da floresta e de tudo que nela vive e reluz. Entre os crescentes barulhos das cidades, o silêncio se coloca como questão fundamental à arte, sendo parte de composição e modo de "tocar" o leitor/espectador (KEMPINSKA, 2008, p. 184) de uma maneira outra, ou seja, a revisão do silêncio e inaugura uma nova perspectiva relacional no mundo moderno - a qual, reitere-se, é citadina e se contrapõe ao barulho.

O silêncio que retorcia perspectivas artísticas na virada dos séculos XIX e XX e abria possibilidades experimentais às primeiras vanguardas do século passado sofreu, ele mesmo, uma torção com o advento do Horror que encerraria a Belle Époque europeia e levaria o mundo, em poucas décadas após a Primeira Guerra Mundial, à Shoah e às políticas de extermínio que marcaram o início de um período contemporâneo, incertamente "pós-moderno". Silêncio passa então a estar sempre contraposto à ideia de representação, gerando, no desconfortável estado das coisas do período pós-guerra, a ascensão lenta de uma nova reflexão sobre a memória (impregnada de muitos "silêncios significantes"). Categorias ainda muito fortes, apesar das novas frentes em que ele se coloca atualmente, a memória e a representação são topos da segunda metade do último século, sendo a pendularidade entre esquecimento e lembrança uma permanente irresolução nos debates que se atentavam às ruínas de mundos no pós-guerra. Em um mundo visto como catastrófico, a reconstrução de algo comum perpassou um longo trabalho de escuta. A filosofia e a arte passaram a se atentar à figura da testemunha, aos tantos testemunhos que, nos seus diferentes tempos, passaram a quebrar o silêncio que parecia ser a solução respeitosa à memória do horror. As obras de Primo Levi, sobrevivente do Lager, por exemplo, se tornaram um grande referencial aos estudos sobre memória. A escuta emerge da 
obra de Levi como algo essencial ao sobrevivente, àquele que quer, de algum modo, tocar um outro com a experiência de atravessar o Horror (1978, apud BAVESI, 2012, p.51-52). Levi formulou a expressão "arte de ouvir", uma arte que era escassa nos anos que se seguiram à guerra: como ninguém mais aguentava remoer os acontecimentos da guerra, prestar atenção no sobrevivente se tornou uma atitude a ele muito cara. A testemunha, tantas vezes retratada envolta em seu silêncio, era e é uma possibilidade de rememoração de um mundo que permanece virtualmente acessível (e, assim, com potência de agir sobre este mundo). O silêncio, enquanto ambiência de tudo que resta da Shoah, é uma possibilidade de acesso aos mundos que foram vertidos em ruínas, fazendo com que estas passem a falar e a influir na existência de um mundo que não se pretende unívoco.Desse modo, o silêncio não poderia mais ser apreendido como unívoco. Não descarto com isso as reflexões de importantes filósofos como Levinas, Adorno ou Blanchot acerca do silêncio após a Shoah: a dimensão do respeito que acompanha a memória não é, de forma alguma, descartável no debate sobre o silêncio contemporâneo. Afinal, os embates entre representação e não-representação ("silêncio") nunca se reduziram a um patamar moral, mas antes à própria reflexão do que se faria com um mundo que havia se reinventado por algo (o silêncio) que era capturado pelo luto.

O silêncio citadino atravessou o mundo moderno - ao mesmo tempo que se tornava carrega potência de memória, não deixava de ser método de alienação de si, de acesso a um pretenso utopos, uma espécie linha de fugada urbe enquanto totalidade ("mundo"). Esse silêncio que aprendemos na cidade se inscreve como limite intransponível, mas é, em realidade, inatingível (LAPOUJADE, 2017, p. 110), um desejo permanente de não ser cidade. Assim, o silêncio que começou a dar voz aos restos e foras do mundo civilizado após a Shoah é uma provocação permanente a novaspossibilidades de mundo. Ainda que o Ocidente construído sob a ideia do Um exija o silêncio enquanto ausência, um silenciamento, uma desatenção frente ao Horror à vida,em outros mundos, onde a mudança de perspectiva no silêncio nunca cessou de produzir efeitos, dos modos mais errantes, silêncio nunca se apartou da vida (seja como memória ou como um fazer constante). Um desses efeitos, sem dúvidas é a vida e obra de Paul Celan, poeta que nos legou a indecidibilidade sobre o silêncio da pedra judia.

\section{Paul Celan em uma tradução}

Paul Celan escreve a partir de ausências e com elas remolda sua Muttersprache (língua materna) alemã, não a deixando se reduzir a um resto da Mördersprache (língua assassina) nazista. Para tanto, o silêncio e o obscuro são essenciais - algo que críticos que foram seus 
contemporâneos, bem como críticos nossos contemporâneos, insistiram em chamar depreciativamente de hermetismo -, assim como a quebra, ou "tritura", nas palavras de Kohl Bines (2008), da língua alemã, sintaticamente arrasada na poesia celaniana. Uma poética que se mostra por feixes de luz em meio à escuridão, como um solo arrasado em que restam vestígios de mundo - o mundo do iídiche, das sinagogas do leste europeu, das culturas ortodoxas e cosmopolitas dos judeus que atravessaram milênios em territórios europeus. Nesse solo poético de Celan escutamos tanto o iídiche quanto o hebraico, aparecendo de maneira evidente ou não, em uma poética atravessada pelo signo judeu. Assim, nos seus poemas lemos com frequência referências ou palavras extraídas diretamente dos idiomas iídiche e hebraico, abrindo variadas possibilidades de leitura - como por meio da mística judaica - eis que o texto cifrado celaniano, "obscuro porque poético", como ele mesmo diria, é um texto que é construído por e exige atenção.

Atenção é algo central à produção celaniana, desde seus poemas até suas traduções. Algo que motiva uma relação com o outro, além de criar um tempo próprio de leitura e imersão no solo arrasado. Escreve Paul Celan (2005, p. 151, fragmento 267.2) em um manuscrito do provável ano de 1959: Die Aufmerksamkeit des Lesers: Eine Zuwendung zum Gedicht ("A atenção do leitor: uma devoção ao poema"); em que Zuwendung ( $z u+$ Wendung, uma viração (Wendung) em direção a $(z u)$ algo) também pode significar "atenção", mas uma atenção que me parece necessitar de um gesto do corpo de quem lê. Uma atenção que move o corpo, curvao, torce-o, modifica-o, criando um gesto atento de travessia a um outro outro. A tradução imersa na obscuridade do poético de Celan é uma travessia que exige o gesto do corpo, o gesto da atenção, um processo de metamorfose. Esse gesto corporal tradutório é mais do que uma pesquisa etimológica em Celan, ou seja, de uma busca por um ět é uma escavação arqueológica, uma experiência relacional que perpassa a $\dot{\alpha} \rho \chi \dot{\eta}$, o antigo, uma espécie de (re)começo, para chegar ao outro e, com ele, esboçar um rastro originário de enlace. "A origem", afinal, escreve Benjamin

apesar de ser uma categoria totalmente histórica, não tem nada que ver com a gênese. O termo origem não designa o vir-a-ser daquilo que se origina, e sim algo que emerge do vir-a-ser e da extinção. A origem se localiza no fluxo do vir-a-ser como um torvelinho, e arrasta em sua corrente o material produzido pela gênese. O originário não se encontra nunca no mundo dos fatos brutos e manifestos, e seu ritmo só se revela a uma visão dupla, que o reconhece, por um lado, como restauração e reprodução, e por outro lado, e por isso mesmo, como incompleto e inacabado. [...]A origem, portanto, não se destaca dos fatos, mas se relaciona com sua pré e pós-história. (BENJAMIN, 1984, p. 67-68) 
Tal origem de que fala Benjamin, atada tanto à sua pré-, como a sua pós-história, não se constitui como verdade imanente, mas antes como algo afetado por um encontro e suas decorrências.Da frequentação a Celan (KULISKY, 2017, p. 6), surgiu-me a ideia de tentar traduzir o seu solo arrasado, cheio de ruínas, muitas manifestas, como já dito, no iídiche e no hebraico, a partir da história que afeta a nossa língua. Para tanto, a arqueologia enquanto modo de dar atenção, me foi essencial. Por meio dela comecei a esboçar a ideia de arqueologia especulativa - conceito que derivei das ideias de Juan José Saer e Alexandre Nodari (2015) de literatura como uma antropologia especulativa. Não apenas uma arqueologia, mas algo que especulasse sobre o solo que incrusta no objeto de si retirado, e também sobre o solo que fica com a marca (temporária ou não) do que ali esteve e se foi.

Não há simplesmente alemão na poesia de Paul Celan, há uma Babel de memórias em fragmentos, de dores e luto: a língua de testemunho se constrói de forma delicada em uma conjunção entre a forma arduamente trabalhada e a mensagem que não se fecha em si, mas se abre a possíveis diálogos. Tenho como hipótese que o português brasileiro é também uma língua de testemunho, o qual carrega ruínas do genocídio fundador da América - e que, pela ausência de memória, nunca cessou. Para escavar esse solo, esta língua, é necessário o olhar arqueológico, a atenção sobre o silêncio. Ao extrair pedaços da casca de uma velha bétula - que talvez estivesse ali desde os horrores da Shoah -Georges Didi-Huberman se debruça sobre as invisibilidades dos grandes atos de horror no complexo Auschwitz-Birkenau e escreve o belíssimo "Cascas". As paisagens, o chão, as cascas das árvores - registros históricos desconsiderados ou apagados em uma névoa de desimportância frente aos grandes atos e fatos históricos, ganham novo olhar:

Sim, é exatamente isto, sim, é isto que ainda resiste ao tempo: é de fato esta estrada, este caminho, são de fato estas duas cercas de postes de cimento e arame farpado. Apesar de agora vazio de todos os atores de sua tragédia, este é claramente o lugar de nossa história. O fogo da história passou. Partiu como a fumaça dos crematórios, soterrados junto com as cinzas dos mortos. Isso significaria que não há nada - ou muito pouco - a ver? Certamente não. Olhar as coisas de um ponto de vista arqueológico é comparar o que vemos no presente, o que sobreviveu, com o que sabemos ter desaparecido. (DIDI-HUBERMAN, 2017, p. 40-41)

Aos nazistas que explodiram o prédio para suprimir as "provas" de seu empreendimento criminoso, não ocorreu a ideia de destruir os solos. Nada se parece mais com um chão de cimento do que outro chão de cimento. Mas, como é sabido, o arqueólogo defende outro discurso: os solos falam conosco precisamente na medida em que sobrevivem, e sobrevivem na medida em que os consideramos neutros, insignificantes, sem consequências. É justamente por isso que merecem nossa atenção. Eles são a casca da história. (DIDI-HUBERMAN, 2017, p. 65-66) 
Imagino que as línguas também tenham cascas insuspeitas, estranhamentos que surgem a olhares atentos. A força do gesto arqueológico está em evidenciar esses restos que nos habituamos a enxergar como "naturais". À arqueologia especulativa caberia um gesto de revisão das permanências em nossa língua (por vezes de mundos que deixaram de existir), uma mirada especular para uma possibilidade outra de existir etraduzir. $\mathrm{O}$ tradutor torna-se, desse modo, testemunha do que é escavado e extraído do solo da língua, numa aproximação com a ideia de Jeanne Marie Gagnebin sobre a testemunha, aquele que "não vai embora, que consegue ouvir a narração insuportável do outro e que aceita que suas palavras levem adiante, como num revezamento, a história do outro" (GAGNEBIN, 2009, p. 57).Memória, afinal, não é apenas uma posse e uma possessão de um indivíduo, é também uma dimensão coletiva, como uma língua, como um solo; cito Didi-Huberman:

\footnotetext{
Walter Benjamin compreendia a memória não como a posse do rememorado - um ter, uma coleção de coisas passadas -, mas como uma aproximação sempre dialética da relação das coisas passadas a seu lugar, ou seja, como a aproximação mesma de seu ter lugar. (DIDI-HUBERMAN, 1998, p. 174)
}

Ao que Huberman cita o próprio Benjamin:

\begin{abstract}
Ausgraben e Erinnern.- A língua explicita este fato: que a memória não é um instrumento que serviria ao reconhecimento do passado, mas que é antes o meio deste. Ela é o meio do vivido, assim como o solo é o meio no qual as cidades antigas jazem sepultadas. Aquele que busca aproximar-se de seu próprio passado sepultado deve se comportar como um homem que faz escavações. [...]E se engana completamente quem se contenta com o inventário de suas descobertas sem ser capaz de indicar, no solo atual, o lugar e a posição onde está conservado o antigo. Pois as verdadeiras lembranças não devem tanto explicar o passado quanto descrever precisamente o lugar onde o pesquisador tomou posse dele. (BENJAMIN apud DIDI-HUBERMAN, 1998, p. 175)
\end{abstract}

$\mathrm{Na}$ continuação desta reflexão, Didi-Huberman escreve brevemente sobre o que acontece com o solo quando da escavação: "o ato de desenterrar um torso modifica a própria terra, o solo sedimentado - não neutro, trazendo em si a história de sua própria sedimentação onde jaziam todos os vestígios" (1998, p. 175-176); o que representa o ato memorativoe desemboca na ideia do autor de presente reminiscente. Essepresente reminiscente, a história da sedimentação do que escavamos na língua de testemunho, no solo arrasado, é um dos resultados do gesto arqueológico da tradução, o qual funda a arqueologia especulativa. A especulação como exercício de memoração, de estranhar o tido à mão, de estranhar o agora: alterizar o espelho tradutório a partir da frequentação do Outro. É necessário especular porque só há restos, porque não há que se resignar à evidência desmemorial do presente. Em nossas línguas, a 
história do mundo permanece, talvez no contínuo limiar do esquecimento. Traduzir também pode ser um gesto de rememoração. Assim, trago a tradução de "Das leise Gemerk" de Paul Celan em um gesto de arqueologia especulativa, a fim de resgatar a potência de seus procedimentos, queevidenciam um dizer e uma escuta que não se resignavam ao silenciamento de uma história positiva. Esse resgate é feito pela rememoração, em nossa língua, de mundos ameríndios, que têm suas marcas incrustradas em nosso dizer cotidiano.

Das leise Gemerk, feucht noch von Augen: dein Weg

knüpft sich hinein. ${ }^{\mathrm{ii}}$
$\mathrm{O}$ rastro gentio

ainda úmido dos olhos:

teu apé

cipó que a sy amarra. ${ }^{\mathrm{iii}}$

Essa tradução é feita entre de silêncios que se cruzam e que se encontram em um foris. Ainda que até aqui se tenha falado majoritariamente sobre o silêncio que adveio da catástrofe e da cidade, nessa tradução há também o impacto do silêncio que comecei a aprender estudando artes verbais ameríndias. Em verdade, é o impacto do deslocamento da ideia de silêncio que a leitura e escuta de etnologias e, principalmente, de palavras, dizeres, cantos, poesias, grafismos em geral e ideias indígenas me proporcionou. Aprender a escutar esse silêncio é o início de um processo de metamorfose que reverbera em tudo que chamamos tradução. Zuwendung, imagino, pode ser o que nos resta enquanto técnica de altercorporação, de devir-tradutor, de ouvir no silêncio da floresta, uma alternativa ao violento silêncio da cidade.

\section{0 silêncio da floresta}

Um diálogo de décadas entre o antropólogo Bruce Albert e o pajé yanomami Davi Kopenawa resultou, dentre outras coisas, em "A queda do céu”, obra seminal recentemente traduzida do francês ao português brasileiro (2015). É essencialmente o contato com "A queda do céu" que me trouxe o lampejo de repensar a ideia de silêncio com a que vinha trabalhando até então nas traduções de Paul Celan,junto à leitura de "A floresta poliglota" (2018) de Bruce Albert, cuja epígrafe é um trecho de "A queda do céu”,no qual Kopenawa reflete sobre a cidade dos brancos em contraposição à floresta em que nasceu e cresceu:

Na cidade, nunca é possível ouvir com clareza as palavras que nos são dirigidas. As pessoas precisam ficar coladas uma na outra para poderem se ouvir. O zumbido das máquinas e dos motores atrapalha todos os outros sons; a algazarra das rádios e televisões confunde todas as outras vozes. É por causa de toda essa barulheira na qual eles se apressam durante o dia que os brancos estão sempre preocupados. Seu coração 
bate depressa demais, seu pensamento fica emaranhado de tonturas e seus olhos estão sempre alerta. Acho que esse ruído contínuo impede seus pensamentos de se juntarem um ao outro. Acabam lá parados, espalhados a seus pés, e é assim que se fica bobo. Mas talvez os brancos gostem desse barulho que os acompanha desde a infância? Para os que cresceram no silêncio da floresta, ao contrário, a barulheira das cidades é dolorosa. É por isso que, quando fico lá muito tempo, minha mente fica tampada e vai se enchendo de escuridão. Fico ansioso e não consigo mais sonhar, porque meu espírito não volta à calma. (ALBERT; KOPENAWA, 2015, p. 437, o trecho grifado é a epígrafe comentadaiv)

A urbe, locus moderno por excelência, com seu barulho é apresentada aqui como um lugar de confusão, em que a mente "fica tampada". Além disso, o barulho das cidades é doloroso a quem está acostumado ao silêncio da mata, disso podemos depreender que o barulho/silêncio age diretamente no corpo do tradutor/pajé, ainda que a relação entre ambos não se coloque como algo necessariamente estimulado. Parto disso para pensar na tradução enquanto metamorfose (aceitando, assim, a separação entre essas palavras, ainda que etimologicamente existam em situação de sinonímia). A fumaça da xawara que está impregnada no mundo dos brancos, corrompendo-nos e adoecendo-nos, age também ao relegar à desatenção o silêncio, ao puro barulho que desconcentra e incute a dor no corpo. A percepção direta de Davi Kopenawa sobre o corpo citadino demonstra o nível técnico extremamente alto de conhecimento corporal, derivado do controle sobre técnicas da metamorfose - o xamã, afinal, é "versado" em transformação de si, em uma forma cosmológica de diplomacia e em transporte a outros mundos. A Aufmerksamkeit e a Zuwendung celaniana, que exigiam a curvatura/devoração/modificação do corpo do Eu e do Tu para criar o afeto de um possível Meridiano, talvez tenham na "técnica tradutória"v da pajelança (assumida aqui lato sensu, numa perspectiva das terras baixas da América do Sul, como modificação corporal e desenvolvimento da atenção que, assim, possibilitam conversação de mundos) ressonâncias interessantes.

A ideia de atenção celaniana é aqui pensada, portanto, tanto como um elogio à multiplicidade, quanto como uma técnica de criação de multiplicidade — de instaurar, ou melhor, restaurar, por exemplo, Czernowitz e seus habitantes, o mundo judeu do leste europeu, neste mundo. Essa restauração é também uma modificação silenciosa da língua (não mais alemã): o silêncio de Celan não se reduz ao "branco significante" mallarmaico, mas é também de imersãoda palavra em Dunkelheit (“obscuridade”, berço da poesia segundo o poeta), em silêncio: na linguagem em silêncio a vida foi escutada.Diferentemente da ideia blanchotiana, ou melhor, de certa tradição filosófica, da relação entre língua e morte ${ }^{\mathrm{vi}}$, de compreender que dizer envolve a ausência da "coisa" real e, portanto, sua morte, o silêncio celaniano e da biofonia da mata é um silêncio de vida. Dizer/traduzir não é suprimir a coisa, mas com-versar a coisa. $\mathrm{O}$ 
silêncio e sua atenção são a trilha da multiplicidade de mundos, a qual exige um corpo atento, maleável, disposto à escuta e à metamorfose. Como escreve Albert: "É esta vocação mimética - esse "tornar-se-imagem xapiri" (xapiripruu) - visando restaurar a condição humana e animal dos primeiros antepassados e deixar as tribulações mitológicas da especiação para trás, que vem a ser o objeto primordial de aprendizado dos jovens xamãs" (2018), a multiplicidade anterior à especiação é o que visa a técnica tradutória da metamorfose, a múltipla pura língua. A calma e o silêncio da floresta, a sua biofonia, são a harmonia da pura língua, diferentemente da ausência de harmonia da urbe, cujo silêncio é a desatenção induzida, a ausência e a morte (o silêncio da cidade é querer a não-cidade, a pura negação). Na busca pela harmonia, pela música, pela poesia, John Cage estranhou seu mundo-urbepela escuta atenta do silêncio:

\footnotetext{
Em sua experiência em uma câmara anecóica - espaço construído para vedar a entrada do som externo, de modo a reverberar apenas a produção ocorrida dentro da câmara - tendo permanecido sozinho e em silêncio, Cage relata ter ouvido dois sons: o de seu sistema nervoso e de sua circulação sanguínea. Esses dois sons são presenças constantes na vida de qualquer ser humano, mesmo quando relegados a uma impercepção devido ao grande volume sonoro externo ao qual estamos expostos, ainda assim os sons do nosso corpo não deixam de nos acompanhar. $\mathrm{O}$ experimento de Cage resulta na compreensão de que o silêncio, como é compreendido - como ausência de sonoridade -, não existe para o ser humano. (CUNHA, 2017, p. 237)
}

A sua descoberta, o silêncio enquanto vida dentro do corpo, ou "corpo volumoso do silêncio" (LAPOUJADE, 2017, p. 111), é uma aproximação com a técnica da metamorfose. Assim também ocorreu com a movimento da etnopoesia norte-americana, essencial aos tradutores brasileiros contemporâneos das artes verbais ameríndias (que presentes estão em sua ausência nesse breve artigo). Cage e a etnopoesia, num tardio modernismo norte-americano, passaram a deslocar o silêncio para a vida. A "tradução total" de Jerome Rothenberg, proposta que, assim como quase toda a teoria da etnopoesia, absorveu muito do advento da performance e de seus novos vazios/silêncios, é um convite à escuta atenta do que era ignorado pela tradução etnográfica até então:

Decidi traduzir os vocábulos \&, a partir disto, já estava jogando com a possibilidade de traduzir outros elementos das canções que normalmente não são contemplados pela tradução. Também pareceu importante ficar tão longe quanto possível da escrita. Então comecei a falar, e depois a cantar minhas próprias palavras em cima da gravação de Mitchell, substituindo os vocábulos dele com sons que me pareceram relevantes, gravando a seguir minha versão numa nova fita cassete, tendo que daí explorá-la em suas próprias condições. Também não foi fácil para mim romper o silêncio ou ir além dos níveis de entonação superficiais de minha fala [...] (ROTHENBERG, 2006, p. 54) 
Tradução é remanência. É um meio de entrega \& de se trazer à vida. Ela começa com uma mudança obrigatória de idioma, mas também uma mudança que abre a possibilidade de uma maior compreensão. Tudo nestes poema-canção é finalmente traduzível: palavras, sons, voz, melodia, gestos, acontecimentos, etc., na reconstituição de uma unidade que seria quebrada se cada elemento fosse abordado separado. Uma experiência plena \& total dá início ao processo, e só uma tradução total pode reproduzi-la por completo. (ROTHENBERG, 2006, p. 60)

Assim como em Cage, vemos a vida florescer na escuta atenta de Rothenberg. A tradução total que "rompe o silêncio" da urbe, do Um, é um elogio à pletora de possibilidades que reside em um trânsito e transe de mundos. A escrita, ainda que silencie uma série de elementos que compõem as artes verbais que Rothenberg traduz, jamais deixa de estar impactada por eles em sua produção: o texto e o corpo são outros, a poesia se molda como partitura ao cantor de um mundo em trânsito. Por mais que propostas do movimento etnopoético estejam em partes datadas, a ideia de tudo traduzir quando tudo se torna perceptível, quando o silêncio é manifestação de vida e mundo, é ainda algo não totalmente absorvido nas teorias da tradução. Por um lado, Dennis Tedlock, em seu “Learning to listen” (1975), procura aproximar as artes verbais ameríndias da poesia dramática, ou seja, de uma forma textual que exige do 24 corpo a sua modificação conjunta à performance. Por outro,Menezes Bastos, etnomusicólogo que cunhou a ideia de "audição de mundo", relata uma experiência que teve com um informante Kamayurá quando com ele foi pescar:

Em um dado momento, Eweka parou de falar e remar, fez-se silencioso e pediu-me silêncio, indicando-me com gestos o fundo da lagoa. Baixinho, disse-me para ouvir o que vinha dali. Apesar de todo o esforço, eu nada ouvi provindo do fundo das águas. Ele insistentemente dizia-me — "você não está ouvindo, peixe cantando? Ouça, ouça..." Eu nada escutava. Isto durou alguns minutos. Passado o episódio, concluí que Eweka tivera um surto alucinatório, de inspiração poética ou de êxtase santo, todo o ocorrido tendo tido, assim, realidade puramente imaginária. Recordo que, dias depois, ele simplesmente disse-me que eu precisava treinar a minha audição (2012, p. 7, apud PINHEIRO DIAS, 2017, p. 26)

A escuta da biofonia é um treino, uma técnica, da qual a técnica da metamorfose é fruto. Fora do paradigma representacional, a metamorfose enquanto técnica tradutória é o contato com a silêncio vivo do foris que nos cerca. Essa é a lição tradutória de Davi Kopenawa e de tantos outros, a sobrevivência da tradução (e, por conseguinte, dos mundos e de suas relações) perpassa necessariamente a preservação da floresta. A atenção celaniana, assim, é mais do que um exercício de rememoração, é antes uma afirmação de vida e uma reabertura da trilha que leva à presença enquanto convivência. Dessa convivência com outros silêncios, o tradutor pode aprender, pela escuta, formas de mudar seu próprio corpo citadino. Além de uma hipótese, a 
metamorfose da tradução é um longo treino que exige rememoração e corpos, os muitos que nos são possíveis. O corpo que traduz também é traduzido e muda.

\section{Metamorfose}

Quando pensava em metamorfose, eu pensava necessariamente na recente "Teoria da Metamorfose", de Emanuele Coccia (2018). Nela, a metamorfose é contraposta à conversão e à revolução, modos por excelência de se pensar a transformação e a técnica nas sociedades urbanas. Para Coccia, nesses dois modos de transformação, tão típicos da modernidade, o mundo se torna extensão do corpo de um sujeito. A metamorfose, por outro lado, obedece a outra "lei do original", em que o corpo se torna extensão do mundo, tendo o casulo como paradigma da técnica:

Um casulo não é um instrumento de autoprojeção para fora dos limites do corpo anatômico. Pelo contrário, corresponde à construção de um limiar onde todas as fronteiras e identidades - tanto do eu quanto do mundo - são suspensas temporariamente. É o quiasma que faz do mundo o laboratório da gênese do eu, e que faz do eu a matéria mais preciosa do mundo, aquela que não cessa de transformá-lo. (COCCIA, 2018)

O “eu” é, assim, sempre um devir-múltiplo, uma potência tradutória, uma potência de pajelança. O silêncio do eu-metamorfose é a harmonia infinita da biofonia (necessariamente poliglota ${ }^{\mathrm{vii}}$ ) ambiente. A técnica xamânica, a modificação corporal, é metamorfose, tradução e, desse modo, faz atenção/Zuwendung, uma memória tornada o virtual sempre acessível e com potencial agência sobre o mundo. Os espíritos e os sopros povoam os mundos, assim como os cristais dos xapiripë. Para a escuta do silêncio são necessárias devoção e calma. O casulo não pode ser rompido, eis que a metamorfose é um processo a ser vivido, em seus tempos.

\footnotetext{
Meu pensamento ainda está procurando. Para conhecer de fato os espíritos, ainda vou precisar estudar muito com a yãkoana. Mas vou fazer isso mais adiante, quando minha mente tiver se acalmado; quando não estiver mais obscurecida pelas palavras tortas dos garimpeiros e fazendeiros; quando eles finalmente pararem de sujar os rios, de derrubar as árvores e de espalhar fumaças de epidemia, vou voltar a beber pó de yãcoana na floresta, silenciosa de novo, e, então, minha atenção poderá enfim se fixar nas palavras dos espíritos. (ALBERT; KOPENAWA, 2015, p. 502)
}

A trilha sonora do xamã é uma trilha quase inversa à que nos foi legada, a qual consiste em fechar-se, isolar-se, ignorar o mundo à volta para criar um silêncio "absoluto", morto, uma negação. A trilha do xamã consiste em técnicas de escuta do silêncio enquanto vida, dos 
cruzamentos de mundos possíveis que o cercam, da presença enquanto múltipla e em convivência. Por isso os sons da floresta são silêncio, eles fazem parte da própria poiésis comum ao corpo do xamã no corpo-mundo. Metamorfose. Multiplicação de casulos.A nós resta de toda essa reflexão uma muda. Como a muda que recebe o abraço etimológico da planta que revive, extraída de um corpo já ido, carregando, numa terra outra, uma potência de corpo, uma metamorfose, assim é a tradução, vida transplantada. Num equívoco arqueológico, ou melhor, numa arqueologia especulativa, a metamorfose enquanto vida transplantada me parece como metáfora suficiente à mudança e à muda que carregam biofonia. Que a tradução não mais seja vaso, mas antes vazante, eis que o silêncio nunca foi falta, mas sempre excesso; excesso de vida que possibilita o transplante redivivo.

\section{REFERÊNCIAS}

ALBERT, Bruce. A floresta poliglota. Traduzido por: Vinícius Alves. 2018. Disponível em: https://subspeciealteritatis.wordpress.com/2018/11/05/a-floresta-poliglota-bruce-albert/. Tradução de: La forêt polyglotte.

ALBERT, Bruce; KOPENAWA, Davi. A queda do céu: palavras de um xamã yanomami. Traduzido por: Beatriz Perrone-Moisés. São Paulo: Companhia das Letras, 2015. Tradução de: La chute du ciel.

AGAMBEN, Giorgio. O que resta? Traduzido por: Vinícius N. Honesko. Disponível em: http://flanagens.blogspot.com.br/2017/06/o-que-resta-giorgio-agamben.html, acesso em 01/06/2019. Tradução de: Che cosa resta?

AGAMBEN, Giorgio. O que resta de Auschwitz. Traduzido por: Selvino J. Assmann. São Paulo: Boitempo, 2008. Tradução de: Quel che resta di Auschwitz.

AGAMBEN, Giorgio. Para uma ontologia e uma política do gesto. Traduzido por: Vinicius N. Honesko. Disponível em: http://flanagens.blogspot.com/2018/03/para-uma-ontologia-e-umapolitica-do.html, acesso em 01/06/2019. Tradução de:Per un'ontologia e uma politica del gesto.

BAVESI, Anna. A língua que salva: Babel e literatura em Primo Levi. Tese de doutorado. Rio de Janeiro: UFRJ, 2012.

BENJAMIN, Walter. A tarefa do tradutor. In: Escritos sobre mito e linguagem. GAGNEBIN, Jeanne Marie (Org.). Traduzido por: Susana Kampff Lages e Ernani Chaves. 2. ed. São Paulo: Editora 34, 2013. Tradução de: Die Aufgabe des Übersetzers.

BENJAMIN, Walter. Origem do drama barroco alemão. Traduzido por: Sergio Paulo Rouanet. São Paulo: Brasiliense, 1984. Tradução de: Ursprung des deutschen Trauerspiels. 
CELAN, Paul. Die Gedichte: Kommentierte Gesamtausgabe. Frankfurt a.M.: Suhrkamp, 2005.

CELAN, Paul. Mikrolithen sinds, Streichen. Die Prosa aus dem Nachlass, edição crítica de Barbara Wiedemann e Bertrand Badiou. Frankfurt: Suhrkamp, 2005.

COCCIA, Emanuele.Teoria da Metamorfose. Traduzido por: Vinicius Alves. 2018. Disponível em: https://subspeciealteritatis.wordpress.com/2018/11/19/teoria-da-metamorfose-emanuelecoccia/, acesso em 01/06/2019. Tradução de: Théorie de la métamorphose

CUNHA, Ester. O silêncio na relação entre arte e vida. Campinas: Unicamp, Anais do XII Encontro de História da Arte, 2017.

DERRIDA, Jacques. Margens da filosofia. Traduzido por: Joaquim Torres Costa e Antônio M. Magalhães, revisão técnica de Constança Marcondes Cesar. Campinas: Papirus, 1991. Tradução de de: Marges de la philosophie.

DERRIDA, Jacques. Shibboleth pour Paul Celan. Paris: Galilée, 1986.

DIDI-HUBERMAN, Georges. Cascas. Traduzido por: André Telles. São Paulo: Editora 34, 2017. Tradução de: Écorces.

DIDI-HUBERMAN, Georges.O que vemos, o que nos olha. Traduzido por: Paulo Neves. São Paulo: Editora 34, 1998.Tradução de: Ce que nous voyons, ce qui nous regarde.

GAGNEBIN, Jeanne Marie. Lembrar escrever esquecer. 2. ed. São Paulo: Editora 34, 2014.

KEMPISKA, Olga Donata Guerizoli. Os impasses da interpretação: o papel do silêncio na recepção da obra poética de Mallarmé e da pintura de Cézanne. Tese de Doutorado. Rio de Janeiro: PUC-Rio, 2008.

KOHL BINES, Rosana. Para ouvir Celan. Poesia sempre, Rio de Janeiro, n. 28, p.234, Ano $13 / 2008$.

KULISKY, Yuri. $O$ Sprachgitter de Celan: uma tradução. Monografia de graduação. Curitiba: UFPR, 2017.

LAPOUJADE, David. As existências mínimas. Traduzido por: Hortência Santos Lencastre. São Paulo: n-1, 2017. Tradução de: Les existences moindres.

MALLARMÉ, Stephane. Mallarmé. Org., traduções e textos críticos de: CAMPOS, Augusto de; CAMPOS, Haroldo de; PIGNATARI, Décio. São Paulo: Editora Perspectiva, 2010.

NODARI, Alexandre. A literatura como antropologia especulativa. Revista da Anpoll $\mathrm{n}^{\mathrm{o}} 38$, p. 75-85, Florianópolis, Jan./Jun. 2015. 
NODARI, Alexandre. O extra-terrestre e o extra-humano: Notas sobre "a revolta kósmica da criatura sobre o criador”. Revista Landa, v. 1, n. 2, 2013. p. 251-261

PINHEIRO DIAS, Jamille.Peles de papel: Caminhos da tradução poética das artes verbais ameríndias. Tese de Doutorado. São Paulo: USP, 2017.

ROTHENBERG, Jerome. Etnopoesia no milênio. COHN, Sergio (Org.). Traduzido por: Luci Collin. Rio de Janeiro: Azougue Editorial, 2006.

SISCAR, Marcos.Poetas à beira de uma crise de versos. In: ALVES, Ida; PEDROSA, Celia (Org.). Subjetividades em devir: estudos de poesia moderna e contemporânea. Rio de Janeiro: Editora 7Letras, 2008.

STROPARO, Sandra.O caminho do silêncio: Mallarmé e Blanchot. Letras de Hoje, Porto Alegre, v. 48, n. 2, p. 191-198, abr./jun. 2013.

TEDLOCK, Dennis.Learning to listen: Oral History as Poetry. In: boundary 2, v. 3, n. 3, p. 707-728. Durham: Duke University Press, 1975.

\footnotetext{
i* Hugo SIMÕES - Bacharel em Direito (2014) e Graduado em Letras - Português e Alemão com ênfase em Estudos da Tradução (2019) pela Universidade Federal do Paraná. Mestre (2019). Mestre (2018) e doutorando em Letras pela mesma instituição. Bolsista CAPES. Universidade Federal do Paraná, Setor de Ciências Humanas, Programa de Pós-Graduação em Letras. Curitiba, Paraná, Brasil.
}

Currículo acadêmico: http://lattes.cnpq.br/7496227329739684

ORCID: https://orcid.org/0000-0002-9322-805X

E-mail: hsimoes.90@gmail.com

${ }^{i i}$ Gemerk é uma palavra arcaica, escavada por Paul Celan, nela reside tanto o sentido de "marcar" (originalmente, "fazer fronteira"), quanto de "lembrar", um particípio do verbo merken. Traduzo por rastro, tanto pela ideia derridiana de origem, quanto pela aproximação das imagens da fronteira e do rastro. dein Weg knüpft sich hinein é um verso de difícil tradução, knüpfen ("atar", mas também se "conectar" com alguém) é aqui um verbo reflexivo que se direciona a (hin) dentro (ein) de sim mesmo. Um caminho que se ata, se conecta, a si mesmo por dentro. Uma leve (tenra) lembrança que ainda está úmida nos olhos.

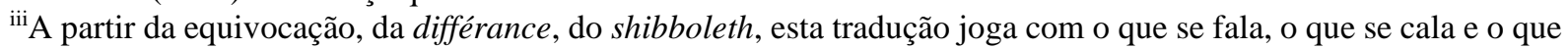
se escuta. Leise pode ser traduzido como "leve", "gentil", o que traduzo por gentio para equivocar. Weg é traduzido por apé - (a)pé é “caminho" em tupi antigo, também equivocando. O difícil knüpft sich hinein é traduzido aqui de forma imagética em um cipó de amarrar, um guaimbê guarani, que aqui se transforma em um cipó de se amarrar equivocado em sy-amarrar - sy- partícula que significa "origem" e "mãe". Um cipó caminho enlaçado em syorigem. Essas pequenas alterações - shibboleth; différance - podem parecer erros gráficos, erros no corpo do texto; o que se diz é o mesmo, mas a marca na escrita é uma reminiscência. Dentro da nossa língua, línguas ágrafas encrustradas, um dizer que invoca mais que a herança europeia. $\mathrm{O}$ exercício arqueológico especulativo neste exemplo é a escuta da equivocação, da miríade de línguas que carrega a história do português brasileiro. Em tradução, portanto, a arqueologia especulativa é o gesto de reescritura do equívoco chamado português brasileiro. O que se diz é muitos e a rememoração disso é um exercício de profunda atenção: uma devoção ao poema, um vislumbre de outro mundo.

iv Na tradução de Vinícius Alves, revisada por mim, optou-se por uma tradução diferente do trecho: "Para aqueles que cresceram no silêncio da floresta, o barulho das cidades é doloroso" (2018).

${ }^{\mathrm{v}}$ Como já se deve ter notado a este ponto, assumo aqui riscos de recaimento em etnocentrismos ao exercer, ainda que de forma controlada, um exercício de bricolagem conceitual. Ainda que a aproximação da tradução com a pajelança não seja novidade, assumo a possibilidade de reducionismos, uma vez que meu objeto de estudo é - em essência - a tradução. 


\begin{abstract}
vi“ Certamente, minha linguagem não mata ninguém. No entanto: quando digo "essa mulher", a morte real é anunciada e já está presente em minha linguagem; minha linguagem quer dizer que essa pessoa que está ali agora pode ser separada dela mesma, subtraída sua existência e sua presença e subitamente mergulhada num nada de existência e de presença; minha linguagem significa essencialmente a possibilidade dessa destruição; ela é, a todo momento, uma alusão resoluta a esse acontecimento. Minha linguagem não mata ninguém. Mas se essa mulher não fosse realmente capaz de morrer, se ela não estivesse a cada momento de sua vida ameaçada de morte, ligada e unida a ela por um laço de essência, eu não poderia cumprir essa negação ideal, esse assassinato diferido que é minha linguagem" (BLANCHOT, apud STROPARO, 2013, p. 195).

vii“"Não é surpreendente, portanto, e em última análise, que a um cosmopolitismo ontológico dos pontos de vista humano e não humano esteja intimamente ligado um poliglotismo "humanimal" de igual complexidade; poliglotismo que, para os Yanomami, dá toda a sua textura sonora à "calma silenciosa" da floresta (tisi ã wai) e se opõe ao "clamor desordenado" (tisi a thethe) da cidade. O confronto entre esse silêncio ordeiro da polifonia de vozes da floresta e nossa cacofonia industrial, que obstrui o pensamento em uma sobrecarga de escuridão (nas palavras de Davi Kopenawa) é precisamente o cerne do trabalho de Bernie Krause, que, como poucos, soube encontrar nos povos autóctones seus mestres em escutar" (ALBERT, 2018).
\end{abstract}

